\title{
Resolving Seasonal Ice Velocity of 45 Greenlandic Glaciers With Very High Temporal Details
}

Vijay, Saurabh; Khan, Shfaqat Abbas; Kusk, Anders; Solgaard, Anne M.; Moon, Twila; Bjørk, Anders Anker

\section{Published in:}

Geophysical Research Letters

Link to article, DOI:

10.1029/2018GL081503

Publication date:

2019

Document Version

Publisher's PDF, also known as Version of record

Link back to DTU Orbit

Citation (APA):

Vijay, S., Khan, S. A., Kusk, A., Solgaard, A. M., Moon, T., \& Bjørk, A. A. (2019). Resolving Seasonal Ice Velocity of 45 Greenlandic Glaciers With Very High Temporal Details. Geophysical Research Letters, 46, 14851495. https://doi.org/10.1029/2018GL081503

\section{General rights}

Copyright and moral rights for the publications made accessible in the public portal are retained by the authors and/or other copyright owners and it is a condition of accessing publications that users recognise and abide by the legal requirements associated with these rights.

- Users may download and print one copy of any publication from the public portal for the purpose of private study or research.

- You may not further distribute the material or use it for any profit-making activity or commercial gain

- You may freely distribute the URL identifying the publication in the public portal 


\section{Geophysical Research Letters}

\author{
RESEARCH LETTER \\ 10.1029/2018GL081503 \\ Key Points: \\ - Sentinel-1 radar data pinpoint \\ seasonal ice velocity variations with \\ high temporal details \\ - Surface melt-induced changes in \\ subglacial hydrology control seasonal \\ ice flow of many glaciers \\ - Seasonal ice flow of ten of the \\ sampled glaciers respond primarily \\ to seasonal terminus changes
}

Supporting Information:

- Supporting Information S1

Correspondence to:

S. Vijay,

sabvj@space.dtu.dk

Citation:

Vijay, S., Khan, S. A., Kusk, A., Solgaard, A. M., Moon, T., \&

Bjørk, A. A. (2019). Resolving seasona ice velocity of 45 Greenlandic glaciers with very high temporal details.

Geophysical Research

Letters, 46, 1485-1495.

https://doi.org/10.1029/2018GL081503

Received 3 DEC 2018

Accepted 30 JAN 2019

Accepted article online 1 FEB 2019

Published online 9 FEB 2019

\section{Resolving Seasonal Ice Velocity of 45 Greenlandic Glaciers With Very High Temporal Details}

\author{
Saurabh Vijay1 ${ }^{(1)}$, Shfaqat Abbas Khan ${ }^{1}$ (D), Anders Kusk1 ${ }^{(i)}$, Anne M. Solgaard², Twila Moon ${ }^{3}$, \\ and Anders Anker Bjørk 4 iD \\ ${ }^{1}$ DTU Space, National Space Institute, Technical University of Denmark, Lyngby, Denmark, ${ }^{2}$ Geological Survey of \\ Denmark and Greenland (GEUS), Østervoldgade 10, Copenhagen, Denmark, ${ }^{3}$ National Snow and Ice Data Center, \\ University of Colorado Boulder, Boulder, CO, USA, ${ }^{4}$ Centre for GeoGenetics, Natural History Museum of Denmark, \\ University of Copenhagen, Copenhagen, Denmark
}

\begin{abstract}
Seasonal glacier ice velocities are important for understanding controlling mechanisms of ice flow. For many Greenlandic glaciers, however, these measurements are limited by low temporal resolution. We present seasonal ice velocity changes, melt season onset and extent, and ice front positions for 45 Greenlandic glaciers using 2015-2017 Sentinel-1 synthetic aperture radar data. Seasonal velocity fluctuations of roughly half of the glaciers appear to be primarily controlled by surface melt-induced changes in the subglacial hydrology. This includes (1) glaciers that speed up with the onset of surface melt and (2) glaciers with comparable late winter and early melt season velocities that show significant slowdown during most of the melt season and speedup during winter. In contrast, less than a quarter of the study glaciers show strong correspondence between seasonal ice speed and terminus changes. Our results pinpoint seasonal variations across Greenland, highlighting the variable influence of meltwater on year-round ice velocities.
\end{abstract}

Plain Language Summary Many Greenlandic glaciers are marine-terminating and seasonal fluctuations in the ice velocity influence ice discharge timing and magnitude. We used Sentinel-1 satellite data to observe seasonal changes in ice velocities, ice front positions, and surface melt conditions for 45 Greenlandic glaciers during 2015-2017, capturing substantial temporal detail. Seasonal velocity variations of nearly half of the glaciers show the strongest correlation with surface melt changes, which seasonally alter the subglacial hydrology. In contrast, less than a quarter of the study glaciers show strong correspondence between seasonal ice velocities and seasonal advance and retreat of the glacier ice front. This study highlights the strong potential influence of surface meltwater on the ice velocities of many Greenlandic glaciers.

\section{Introduction}

Obtaining glacier velocities at high spatiotemporal resolution is important primarily for two reasons: (1) to quantify glacier mass loss due to ice discharge and (2) to understand the glacier response to elements inherent to the glacier system (e.g., glacier geometry and bedrock topography) versus external drivers (e.g., ocean-climate system). Interannual velocity fluctuations and resulting mass loss due to ice discharge via marine-terminating glaciers in Greenland are relatively well characterized (Andersen et al., 2015; Enderlin et al., 2014; Howat et al., 2007; Mouginot et al., 2015; Rignot et al., 2004; Schlegel et al., 2014). For instance, Mouginot et al. (2015) estimated long-term (1976-2015) velocity changes of Zachariae Isstrøm, northeast Greenland, noting significant speedup after 2012, which was primarily attributed to the disappearance of its floating ice shelf and enhanced subsurface melting of its ice front by the ocean. Previous studies have also reported seasonal velocity variability for different glacier systems in Greenland and provided evidence of potential driving mechanisms (Bevan et al., 2015; Howat et al., 2008; Kjeldsen et al., 2017; Moon et al., 2012; Moon et al., 2014; Rathmann et al., 2017). For some of these glaciers, seasonal ice flow was found to correlate with the changes in ice front position (Howat et al., 2010, 2008; Kehrl et al., 2017; Moon et al., 2014). In other cases, processes related to surface melt water input to the bed, including potential changes in the subglacial drainage systems and effective pressures, were found to be responsible for seasonal velocity fluctuations (Bevan et al., 2015; Kehrl et al., 2017; Moon et al., 2014; Rathmann et al., 2017). Drainage of ice-dammed
(C)2019. American Geophysical Union. All Rights Reserved. 
(Kjeldsen et al., 2017) and supraglacial lakes (Howat et al., 2010), which also affect the subglacial hydrology, can also cause prominent ice flow fluctuations.

Despite numerous studies investigating seasonal velocity fluctuations and their driving factors, knowledge is limited by low temporal resolution of the available remote sensing data. As a result, most of the previous seasonal ice dynamics studies in Greenland have been based on sparse velocity estimates throughout the year (Howat et al., 2008, 2010; Moon et al., 2012, 2014). Also, most previous studies have focused on spring-to-summer velocities and associated driving mechanisms. The wintertime velocity changes of Greenlandic glaciers remain poorly investigated. It is evident that several processes influencing velocity fluctuations vary on a seasonal scale and differ from glacier to glacier, including meltwater input to the subglacial system, subglacial water pressure changes, and seasonal terminus retreat/advance. To better understand these processes, it is necessary to quantify velocities with high temporal resolution and with high spatial coverage. The launch of the Sentinel-1 radar mission, with a 6- to 12-day revisit frequency and global acquisition strategy, opens new opportunities for examining seasonal ice velocity with much better spatiotemporal detail (Nagler et al., 2015). Furthermore, Sentinel-1, as a radar system, overcomes the limitations of polar regions optical missions (e.g., Landsat 8 and Sentinel-2), which cannot collect data through clouds or in darkness.

Recent work has used Sentinel-1 data to derive seasonal ice velocities of Greenlandic glaciers (Joughin et al., 2018; Lemos et al., 2018). However, these studies focused on the seasonal ice dynamics of only a few key Greenlandic glaciers (Lemos et al., 2018) or on the presentation of consistent Greenland-wide ice velocity products (Joughin et al., 2018). In this study, we expand on this recent research by investigating high temporal resolution seasonal ice velocity variations of 45 individual marine-terminating glaciers during 2015-01-01 to 2017-12-31 (Figure 1). Our study glaciers are selected to span northeast, southeast, and northwest Greenland. These regions are influenced by different external forcing, such as annual sea ice concentration, melt extent, and melt period length (Andres \& Peltier, 2013). For instance, northeast Greenland has the shortest summer surface melt period compared to the northwest and southeast (supporting information Figures S46 and S47) but is projected to receive more precipitation in the future (Stendel et al., 2007). We also include time-series of ice front positions and radar backscattered intensity, which allows us to document each glacier's melt period onset and length, to explore the mechanisms controlling seasonal velocity patterns. Previously, Moon et al. (2014) presented seasonal velocities (measured 3-6 times per year) of 55 Greenlandic glaciers during 2009-2013, employing modeled runoff records and termini changes to analyze the velocity patterns. We revisit 23 of these glaciers with our dense time-series (30 measurements per year) and analyze 22 additional glaciers providing new insights into the potential mechanisms driving seasonal glacier velocity fluctuations.

\section{Data and Methods}

Synthetic aperture radar (SAR) data from the Sentinel-1 mission is the prime data set used in this study. The Sentinel-1 mission is a constellation of two C-band $(5.405 \mathrm{GHz})$ radar satellites, Sentinel-1A and Sentinel-1B, developed by the European Space Agency (Potin et al., 2014). Sentinel-1A, launched on 3 April 2014, has a repeat orbit cycle of 12 days and acquires data in four imaging modes: Interferometric Wide swath mode (IW), Wave mode (WV), Strip Map mode (SM), and ExtraWide-swath mode (EW; Torres et al., 2012). Following a similar data acquisition strategy, Sentinel-1B, launched on 22 April 2016, increased revisit frequency to 6 days as its 12-day orbit is offset from Sentinel-1A. Our processed data set may be downloaded from https://doi.pangaea.de/10.1594/PANGAEA.894685.

\subsection{Glacier Surface Velocities}

We used Sentinel-1 IW single-look complex images to generate glacier surface velocity maps from SAR intensity offset-tracking between images acquired successively from the same track (Kusk et al., 2018). The revisit time of the individual Sentinel-1 satellites is 12 days, with a 6-day offset between Sentinel-1A and Sentinel-1B. The time-series of velocity maps was generated with 12-day sampling defined by the Sentinel-1A repeat cycle. Since many glaciers were imaged from several tracks, each velocity map is a fusion of measurements from all available tracks observed over 24-day period. Some 6-day Sentinel-1 A/B pairs were also included to increase the spatial coverage in Southern Greenland. Surface movement was derived by assuming surface parallel flow, using the Greenland Mapping Project $30 \mathrm{~m}$ digital elevation model (Howat et al., 2014, 2015). Error estimates were generated by calculating (in radar geometry) the local standard 


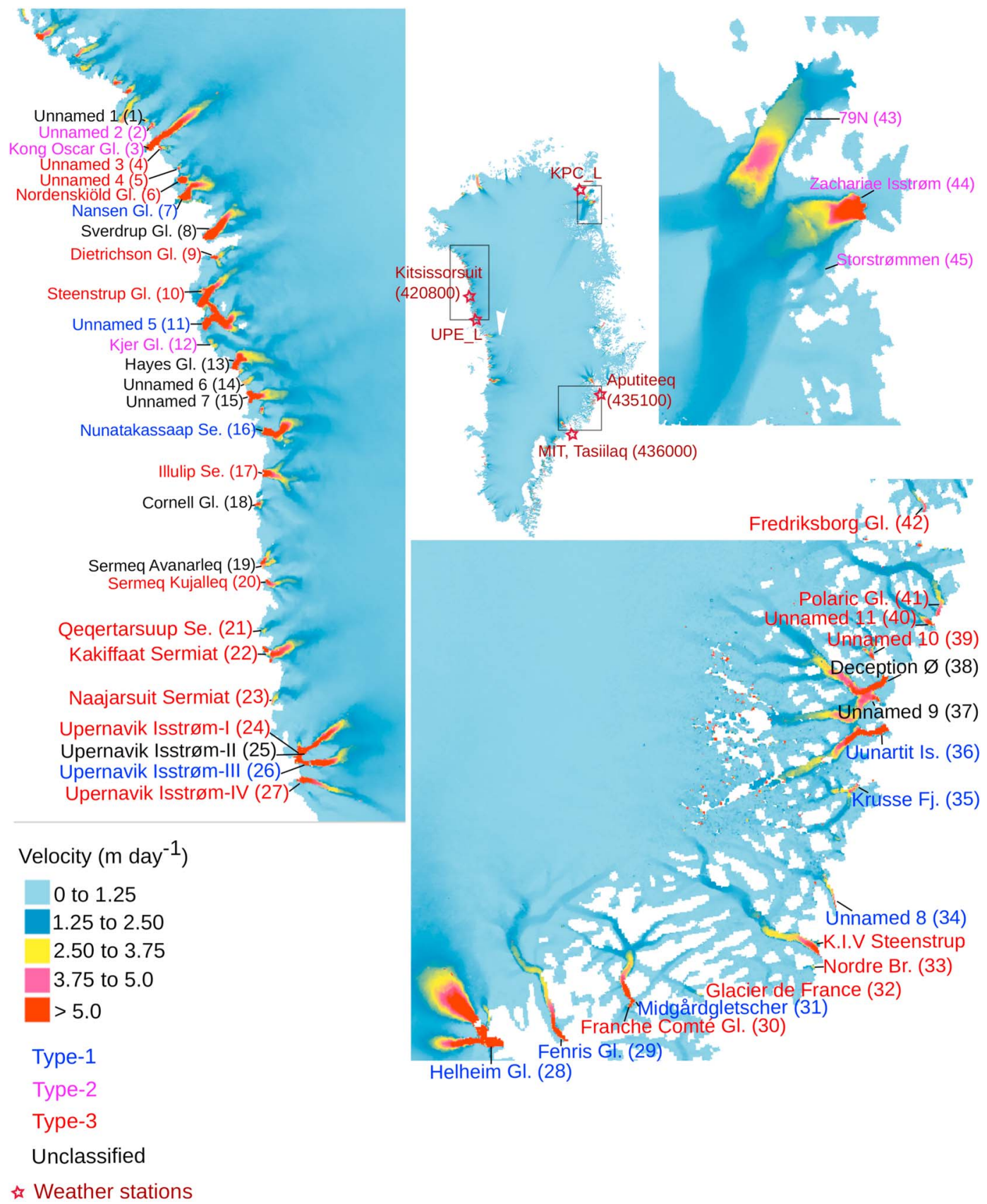

Figure 1. Overview map of Greenland ice velocities showing the locations of the 45 study glaciers and weather stations. The background velocity map belongs to 2018-01-17 - 2018-02-10. These glaciers have been classified as types 1,2 , and 3 while some remained unclassified based on the classification scheme applied in this study.

deviation of the offset maps using a sliding $5 \times 5$ pixel window and projecting the resulting estimates to the output geometry. The error estimates were used to create a weighted average when combining measurements in areas that are covered by several tracks (Kusk et al., 2018).

\subsection{Surface Melt Onset and Melt Period}

We employed Sentinel-1 IW (HH polarization) radar intensity images with temporal resolution of 12 days to identify the onset date of surface melt and measure the melt period length for each individual glacier. The radar images are made available as Ground Range Detected (GRD) products by the European Space Agency. Although the pixel values in GRD products depict the intensity of radar signal returns from the reflecting surface, we further processed them to remove speckles and SAR geometric errors (Veci, 
2015). Pixel intensity values were then converted to backscatter intensity (or backscattering coefficient) measured in decibel $(\mathrm{dB})$. Radar backscatter is high when the signal is reflected from a frozen surface, while it is low when surface melt occurs (Bevan et al., 2015; Trusel et al., 2012). Therefore, we analyzed backscattering coefficient time-series for the period 2015-2017 to determine transitions from frozen surface conditions to surface melt conditions (melt onset timing) using fluctuations between the annual maximum and minimum values. In a few cases of missing 2015 radar backscatter data, we approximated the melt onset based on the 2016-2017 melting trend. We also analyzed air temperatures from available weather stations to validate the surface melt proxy produced from radar backscatter. We used daily mean temperatures from three Programme for Monitoring of the Greenland Ice Sheet (PROMICE) weather stations (UPE_L, KPC_L and MIT; https://www.promice.dk/DataDownload.html; Van As et al., 2011; Figure 1) and hourly mean temperatures from three Danish Meteorological Institute and Greenland Isolated Weather Station (Kitsissorsuit (420800), Aputiteeq (435100), Tasiilaq (436000); https://www.dmi.dk/en/groenland/; Cappelen, 2017; Figure 1).

\subsection{Changes in Front Position}

Radar intensity images have been widely used to map the terminus positions of marine-terminating glaciers (Howat et al., 2008; Kehrl et al., 2017; Moon et al., 2014; Vijay \& Braun, 2017). We used speckle-reduced Sentinel-1 IW GRD radar intensity images to map ice front positions. In the case of missing Sentinel SAR data, we used Landsat 8 Operational Land Imager data to map the ice fronts. We applied the common box method (Moon \& Joughin, 2008), creating a buffer polygon for each glacier and updating the polygon by digitizing the ice front positions at different dates. The results are time-series of glacier area changes.

\subsection{Glacier Classification Based on Seasonal Patterns}

Moon et al. (2014) previously classified the seasonal velocity patterns (3-6 annual observations) of 55 marine-terminating Greenlandic glaciers, combining these results with frontal changes and modeled runoff (as a proxy for meltwater input to the subglacial system). Our classification is based on individual 3-year glacier time-series of nearly 75 surface velocity measurements, 15-30 estimates of ice front positions, and $\sim 40$ radar backscattered intensity values (for identifying surface melt onset and melt season length) during 2015-01-01 to 2017-12-31. We measured the velocity and radar backscatter within $1 \mathrm{~km}$ of each glacier calving front, except for 79N (Figure S43) and Storstrømmen (Figure S45). These ice streams have large floating termini, but the maximum changes take place where they are grounded. Therefore, for $79 \mathrm{~N}$ and Storstrømmen, we sampled the velocity changes close to the grounding line (Figure 1).

We broadly classified the velocity patterns into three different types (type 1, type 2 , and type 3 ). The flow speed of type- 1 glaciers is well correlated with terminus advance and retreat. Type- 2 behavior is characterized by a strong speedup with the onset of surface melt and a similar decline in speed after the mid-melt season. Type- 2 glaciers attained velocity minimums at the end of the melt season, with consistent flow or slight speedup during winters. In most cases, wintertime velocities remained lower than the summer velocity peak. Type-3 behavior shows high and comparable velocities during late winter and early melt season, with consistent slow down during most of the melt season, and attaining velocity minimums at roughly the end of the melt season. For most type-3 seasonal behavior the fall through winter speedup was substantial. We did not classify glaciers that did not show correlation among velocity changes, terminus changes, and surface melt conditions.

\section{Results}

Across our 45 study glaciers, we classified 10 glaciers as type-1 category with speedup coinciding with frontal retreat and slowdown associated with a stable or advancing ice front (e.g., Upernavik Isstrøm-III (26) (Figure 2). Six glaciers were classified as type 2 (e.g., Zachariae Isstrøm (44 in Figure 3) and 19 glaciers fall into the type-3 category, showing melt season deceleration from an early peak velocity (e.g., Upernavik Isstrøm-IV (27) (Figure 4). The seasonal patterns of individual glaciers are shown in Figures S1-S47 (supporting information).

\section{Discussions}

The 10 type- 1 glaciers show a strong correlation between seasonal ice velocity and frontal changes (retreat/advance; Table 1). The type-1 pattern supports the hypothesis that the reduction of resistive stress due to seasonal frontal retreat causes speedup (Bevan et al., 2012; Howat et al., 2008). During 2015-2017, 
Type-1, Upernavik Isstrøm - III (26)

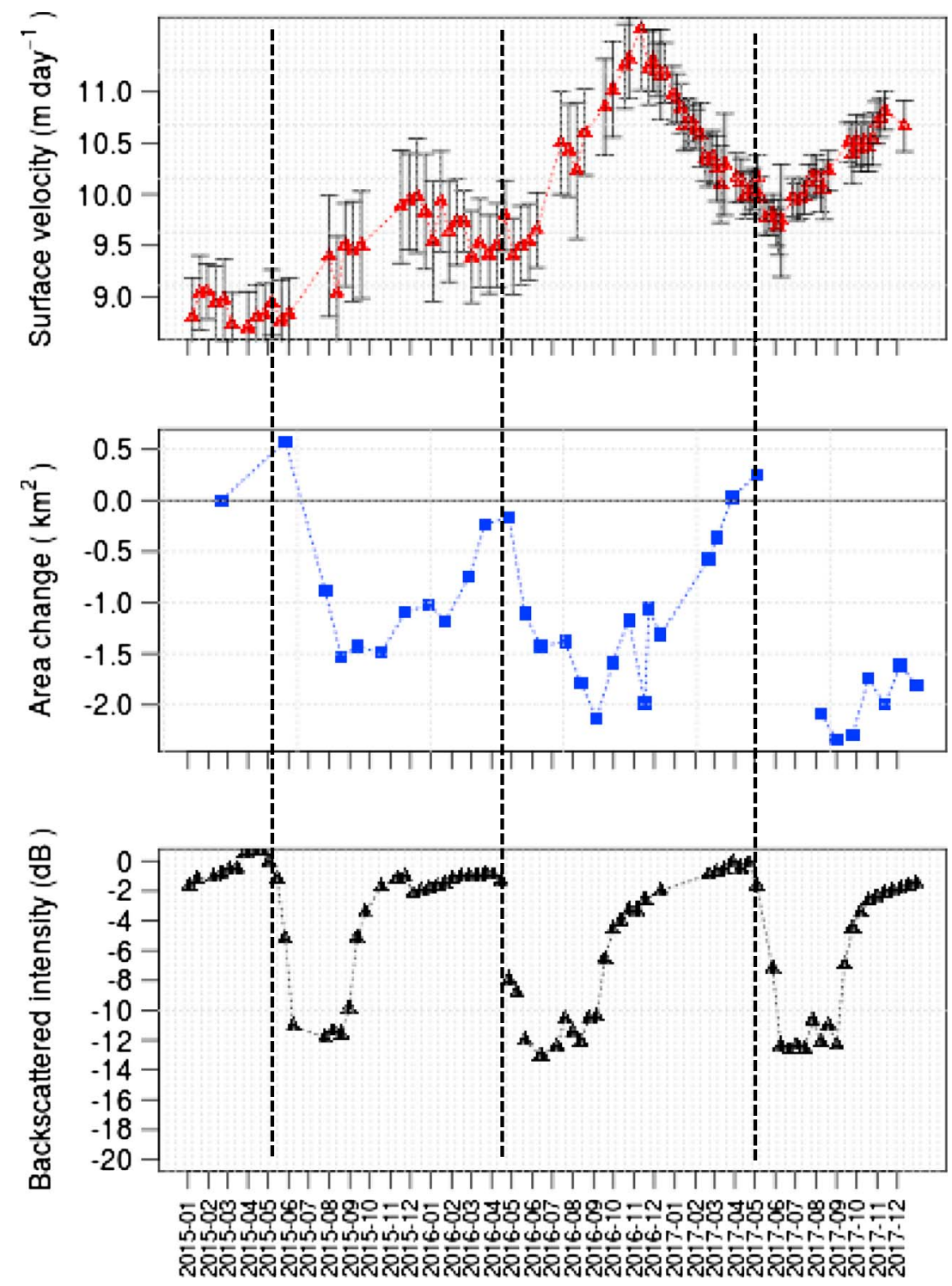

Figure 2. Example showing the type-1 pattern surface velocity together with area change and backscattered intensity during 2015-2017. The vertical dashed line indicates the onset of surface melt as depicted from the seasonal trend of backscattered intensity.

most type-1 glaciers underwent frontal retreat during summer to fall and advanced during winter to spring. Only one type-1 glacier (Midgårdgletscher (31)) did not show prominent seasonal terminus changes, but its strong speedup is coincident with long-term retreat (Figure S31). Previously, Moon et al. (2014) found correspondence between speed and terminus changes for Uunartit Is. (36) during 2009 to 2013. Our dense observations also enabled us to classify Alison Glacier (16), Upernavik Isstrøm - III (26), and Helheim Glacier (28) as type 1 (Figures S16, S26, S28, S36, and Table 1). A link between ice front changes and ice velocities is documented in a number of previous studies (Bevan et al., 2012, Howat et al., 2008, 2010, Moon et al., 2014, Vijay \& Braun, 2017), and our work further supports this connection. For instance, changes in ice front positions at Helheim Glacier (28) and Jakobshavn Isbræ (not measured in this study), two of Greenland's highest discharge glaciers, greatly influence their seasonal velocity variations (Joughin et al., 2018; Kehrl et al., 2017; Lemos et al., 2018).

A different mechanism governs the seasonal behavior of type- 2 and type- 3 glaciers. For these glaciers, the seasonal ice velocity patterns do not correlate with seasonal terminus changes. However, there is a strong 
Table 1

Comparison of Seasonal Behavior With Moon et al. (2014) Also Showing the Mean Altitude of the Observation Area and Annual Velocity of the Studied Glaciers

\begin{tabular}{|c|c|c|c|c|c|}
\hline Glacier number & Glacier name & $\begin{array}{c}\text { 2009-2013 } \\
\text { (Moon et al., 2014) }\end{array}$ & $\begin{array}{c}\text { 2015-2017 } \\
\text { (This study) }\end{array}$ & $\begin{array}{l}\text { Altitude } \\
\text { (m asl) }\end{array}$ & $\begin{array}{l}\text { Annual surface velocity } \\
\text { (m/year) }\end{array}$ \\
\hline 1 & Unnamed 1 & Not studied & Unclassified & 168 & 486 \\
\hline 2 & Unnamed 2 & Type 2 & Type 2 & 227 & 514 \\
\hline 3 & Kong Oscar & Type 2 & Type 2 & 131 & 3,123 \\
\hline 4 & Unnamed 3 & Not studied & Type 3 & 167 & 510 \\
\hline 5 & Unnamed 4 & Type 2 & Type 3 & 279 & 607 \\
\hline 6 & Nordenskiöld Gl. & Type 2 & Type 3 & 238 & 833 \\
\hline 7 & Nansen Glacier & Not studied & Type 1 & 100 & 1,893 \\
\hline 8 & Sverdrup Glacier & Type 2 & Unclassified & 120 & 2,484 \\
\hline 9 & Dietrichson Glacier & Not studied & Type 3 & 211 & 2,109 \\
\hline 10 & Steenstrup Glacier & Unclassified & Type 3 & 233 & 1,198 \\
\hline 11 & Unnamed 5 & Not studied & Type 1 & 163 & 3,117 \\
\hline 12 & Kjer Glacier & Type 2 & Type 2 & 258 & 304 \\
\hline 13 & Hayes Glacier & Unclassified & Unclassified & 150 & 2,392 \\
\hline 14 & Unnamed 6 & Unclassified & Unclassified & 144 & 744 \\
\hline 15 & Unnamed 7 & Type 2 & Unclassified & 242 & 1,217 \\
\hline 16 & Nunatakassaap Se. & Unclassified & Type 1 & 254 & 2,028 \\
\hline 17 & Illulip Sermia & Type 2 & Type 3 & 194 & 1,435 \\
\hline 18 & Cornell Glacier & Type 3 & Unclassified & 149 & 493 \\
\hline 19 & Sermeq Avanarleq & Not studied & Unclassified & 260 & 784 \\
\hline 20 & Sermeq Kujalleq & Not studied & Type 3 & 195 & 1,062 \\
\hline 21 & Qeqertarsuup Se. & Not studied & Type 3 & 180 & 540 \\
\hline 22 & Kakiffaat Sermiat & Not studied & Type 3 & 273 & 1,419 \\
\hline 23 & Naajarsuit Sermiat & Not studied & Type 3 & 130 & 970 \\
\hline 24 & Upernavik Isstrøm - I & Type 3 & Type 3 & 310 & 361 \\
\hline 25 & Upernavik Isstrøm - II & Unclassified & Unclassified & 243 & 5,289 \\
\hline 26 & Upernavik Isstrøm - III & Unclassified & Type 1 & 266 & 3,735 \\
\hline 27 & Upernavik Isstrøm - IV & Type 2 & Type 3 & 125 & 1,938 \\
\hline 28 & Helheim Glacier & Unclassified & Type 1 & 165 & 6,782 \\
\hline 29 & Fenrisgletscher & Not studied & Type 1 & 142 & 2,002 \\
\hline 30 & Franche Comté Gletsjer & Type 3 & Type 3 & 533 & 2,959 \\
\hline 31 & Midgårdgletscher & Not studied & Type 1 & 303 & 80 \\
\hline 32 & Glacier De France & Not studied & Type 3 & 242 & 380 \\
\hline 33 & K. I. V Steenstrup Nordre Br. & Not studied & Type 3 & 469 & 1,248 \\
\hline 34 & Unnamed 8 & Not studied & Type 1 & 588 & 955 \\
\hline 35 & Krusse Fj. & Not studied & Type 1 & 314 & 1,182 \\
\hline 36 & Uunartit Is. & Type 1 & Type 1 & 512 & 2,710 \\
\hline 37 & Unnamed 9 & Unclassified & Unclassified & 270 & 1,420 \\
\hline 38 & Deception $\varnothing$ & Unclassified & Unclassified & 143 & 2,637 \\
\hline 39 & Unnamed 10 & Type 3 & Type 3 & 238 & 804 \\
\hline 40 & Unnamed 11 & Not studied & Type 3 & 261 & 753 \\
\hline 41 & Polaric Gl. & Not studied & Type 3 & 280 & 834 \\
\hline 42 & Fredriksborg Gl. & Not studied & Type 3 & 263 & 1,229 \\
\hline 43 & $79 \mathrm{~N}$ & Not studied & Type 2 & 87 & 1,397 \\
\hline 44 & Zachariae Isstrøm & Not studied & Type 2 & 101 & 2,199 \\
\hline 45 & Storstrømmen & Not studied & Type 2 & 850 & 185 \\
\hline
\end{tabular}


Type-2, Zachariae Isstrøm (44)

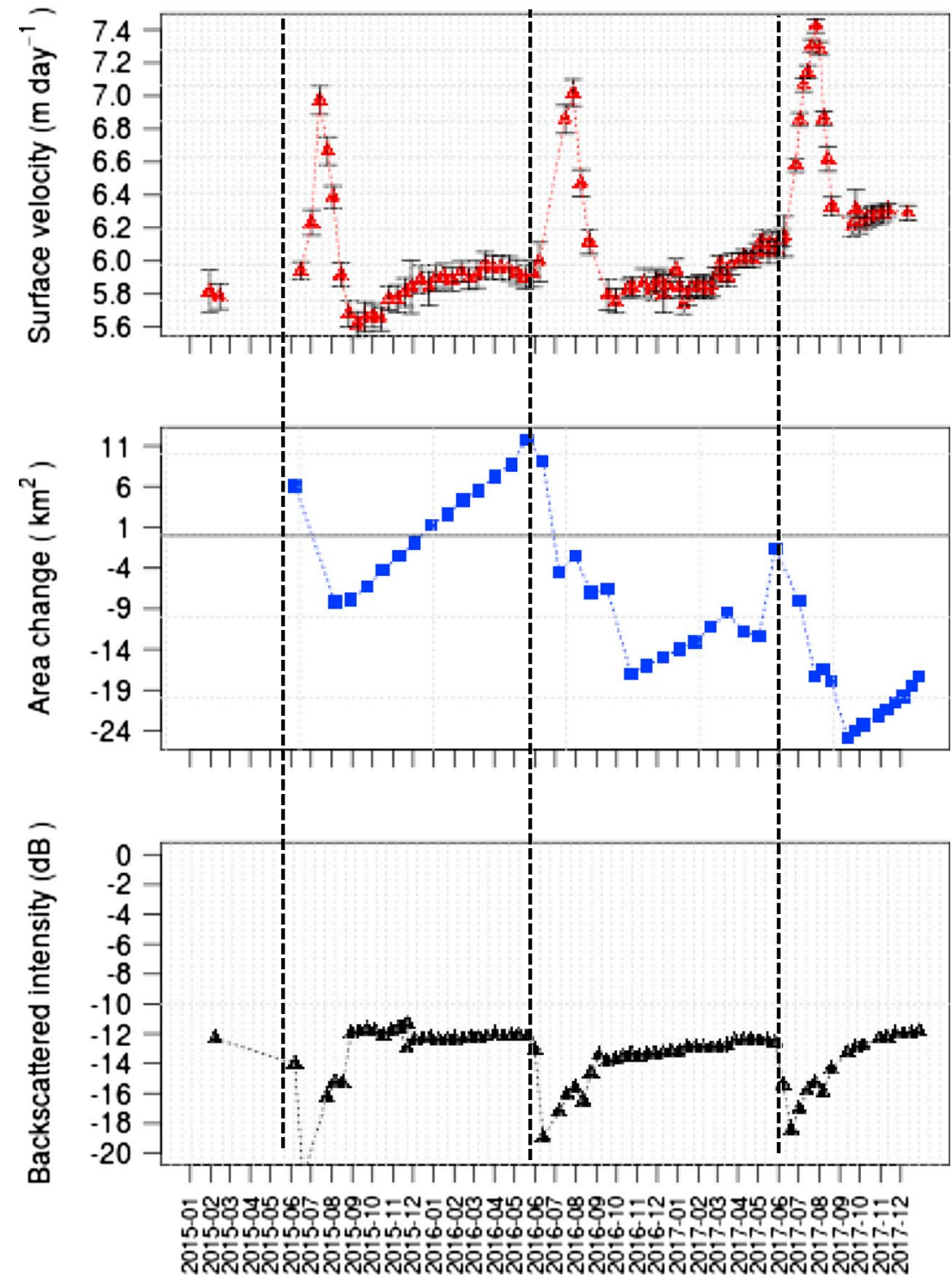

Figure 3. Same as Figure 2 but for type-2 pattern.

correspondence between spring to summer ice velocity changes and surface melt conditions as measured by radar backscattered intensity. We assume that the surface meltwater reaches the glacier bed within hours to days, influencing the subglacial hydrology, and moving through and helping to form subglacial drainage channels (Bartholomew et al., 2010; Kamb et al., 1994; Meier et al., 1994; Sugiyama et al., 2011). Type-2 and type-3 glaciers respond differently to surface melt input to the subglacial system. Type-2 glaciers show prominent speedup (up to 18\%) with the onset of surface melt and a strong velocity drop at the end of the melt season, followed in most cases by slight speedup or consistent through winter. Spring and late summer velocities, in most cases, are similar. In contrast to type- 2 and type- 3 glaciers show muted changes in speed with the melt onset, but the early spring velocity is slightly higher (mostly $<10 \%$ ) or equivalent compared to late-winter velocities. These glaciers show substantial deceleration during most of the melt season. We attribute the differences between type- 2 and type- 3 spring-to-summer behavior primarily to the changes in subglacial hydrology driven by meltwater availability during the melt season. Typically, at the onset of the melt season, the drainage network is not capable of efficiently routing meltwater. As water is added to the subglacial system, subglacial water pressure increases, and consequently, the glacier speeds up (Bartholomew et al., 2010; Sundal et al., 2011). When the subglacial drainage channels become more 
Type-3, Upernavik Isstrøm - IV (27)

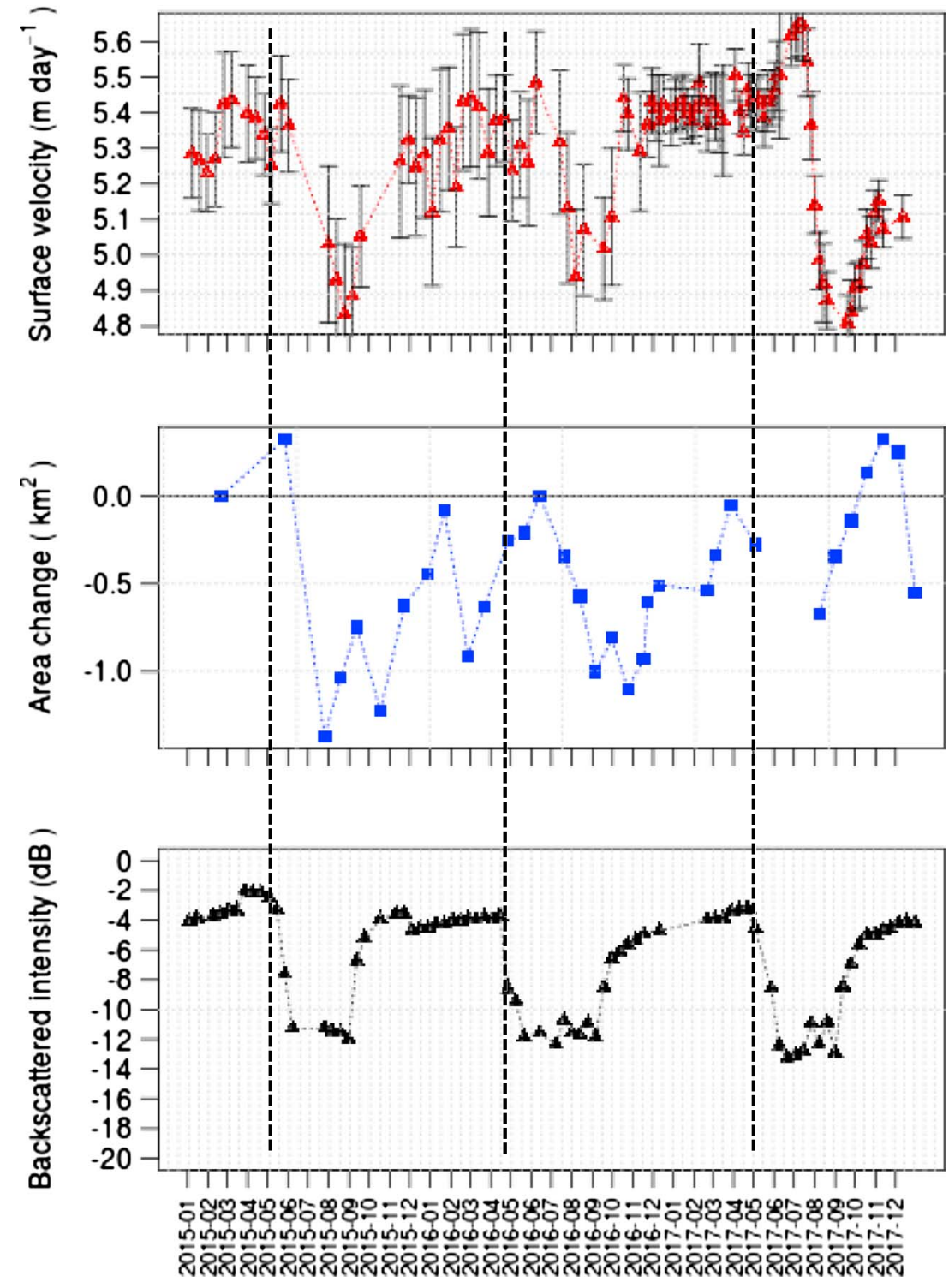

Figure 4. Same as Figure 2 but for type-3 pattern.

channelized and drain meltwater more effectively, both subglacial water pressure and ice velocity decrease (Andrews et al., 2014). Our results suggest that a channelized drainage system develops in both type-2 and type-3 glaciers but at different times of the melt season. In the case of type-2, the drainage system starts to develop in the middle of the melt season. On the other hand, type-3 glaciers appear to develop channelized networks more quickly, close to the onset of the melt season. We speculate that this early development may be linked to a higher supply of basal meltwater during autumn to winter.

In comparison to type-2 glaciers, type-3 glaciers accelerated much more during autumn to winter, attaining velocities slightly lower or equivalent to those of the early spring velocity peak. We hypothesize that the type-3 winter speedup is associated with subglacial meltwater activity. During autumn and winter, subglacial drainage channels tend to close due to viscous deformation (Vieli et al., 2004). Such an inactive hydrologic system primarily contains water from three sources: basal meltwater, ocean water infiltrating into the subglacial system, and meltwater that did not evacuate through channels during the melt season and was retained in the firn and ice body (Brinkerhoff \& O'Neel, 2017). This collective water may increase the subglacial water pressure again during winter and lead to winter speedup. Chu et al. (2016) pointed out that 
glaciers respond differently to the same meltwater input depending on how water reroutes in the subglacial environment. Water availability from the weakly connected and unchannelized networks can potentially increase the subglacial water pressure and basal motion (Andrews et al., 2014; Hoffman et al., 2016). Winter speedup observed at few glacier systems in Yukon, Canada (Abe \& Furuya, 2015) and the Karakoram (Quincey et al., 2009) also suggest that winter water storage can promote basal sliding by inducing subglacial water pressure changes.

We did not include Jakobshavn Isbræ and Kangerlussuaq Glacier in our analysis because they are well investigated by recent studies (Joughin et al., 2018; Kehrl et al., 2017; Lemos et al., 2018). Kehrl et al. (2017) observed two distinct periods of seasonal speedup at Kangerlussuaq Glacier: one in summer caused by surface melt-induced basal lubrication and one in winter due to frontal retreat. Similarly, Lemos et al. (2018) found strong correlation between ice velocity and frontal changes at Jakobshavn Isbræ. If we classify these glaciers based on our classification scheme, Jakobshavn Isbræ falls into the type-1 category, whereas Kangerlussuaq Glacier remains unclassified as it shows mixed patterns.

We also compare results from 23 glaciers common between our study and Moon et al. (2014). This comparison strengthens our understanding of the generalized seasonal glacier behavior by adding time dense observations over three additional years. We also identified seasonal patterns for four glaciers that remained unclassified by Moon et al. (2014). We found 12 glaciers following the same pattern during 2009-2013 and 2015-2017 (Table 1). Four glaciers switched from type 2 during 2009-2013 to type 3 during 2015-2017, possibly indicating interannual variations in subglacial hydrology, which were also observed during 2009-2013 by Moon et al. (2014). For instance, they observed type-3 behavior for Illulip Sermia (17) and Upernavik Isstrøm - IV (Glacier 27) in 2012 and type-2 behavior during the rest of the period. Both Illulip Sermia and Upernavik Isstrøm - IV followed type-3 behavior during our observation period (2015-2017). Changes in water storage and channelization at the bed cause switching between behavior types. Further investigation, however, is needed into subglacial hydraulic potential and the connectivity between subglacial drainage networks (Andrews et al., 2014; Chu et al., 2016). Our dense time-series has also pinpointed velocity changes during seasons (particularly the early melt season) that were not well observed by Moon et al. (2014). Therefore, it is also possible that the glaciers did not change behavior types between 2009-2013 and 2015-2017, rather our dense observations fill the gaps and improve seasonal velocity classifications.

Ice discharge via marine-terminating glaciers varies with seasonal ice velocities (McNabb et al., 2015; Vijay \& Braun, 2017), with total ice discharge constituting 30-50\% of Greenland mass loss (Enderlin et al., 2014). Our results show that glaciers can switch seasonal velocity patterns, which may alter individual interannual glacier mass loss from ice discharge (e.g., due to winter speedup). While recent Greenland-wide and region-wide estimates of annual and interannual ice front changes and ice discharge find strong correlation between these two metrics (King et al., 2018), our results emphasize that this relationship may not hold true for seasonal changes at individual glaciers. Thus, understanding and predicting local ice discharge changes, which influence ecosystem and ice-ocean interactions, likely still requires observations that include hydrologic as well as terminus data.

\section{Conclusions}

We present temporally detailed seasonal changes in velocity, ice front position, melt season onset, and melt season length for 45 marine-terminating glaciers across Greenland. Our observations reveal differences in glacier behavior and document the potential driving mechanisms. Surface melt-induced alterations in the subglacial hydrology and associated changes in the efficiency of subglacial drainage networks appear to control the seasonal velocity changes of most glaciers, while frontal changes influence the seasonal velocity variations for fewer glaciers. The data presented here emphasize the importance of surface melting and associated subglacial hydrology changes for affecting ice velocities in different seasons. In some cases, subglacial hydrologic conditions may be responsible for high wintertime velocities (type 3); increasing wintertime velocities are found in regions with longer melt seasons. Under climate warming, instances of high winter velocities may increase, potentially increasing annual ice velocities and ice discharge. Switching behavior (e.g., from type 2 to type 3 ) caused by changes in subglacial water storage may have similar implications. Understanding these processes is essential for modeling glacier behavior over short time periods, and this study shows the potential for temporally dense measurements to support investigation of key processes governing marine-terminating glacier ice flow. 


\section{Acknowledgments}

The study was funded by the VILLUM FONDEN. The meteorological data were kindly provided by the Geological Survey of Denmark and Greenland (GEUS), within PROMICE programme, and the Danish Meteorological Institute. The Sentinel-1 data were made available by ESA Copernicus initiative, and Landsat- 8 data were obtained from the USGS. S. V. would like to thank Kristian K. Kjeldsen (GEUS) for his useful inputs and ESA EO0 Research and Service Support (RSS) for kindly providing virtual machine for the Sentinel-1 processing.

\section{References}

Abe, T., \& Furuya, M. (2015). Winter speed-up of quiescent surge-type glaciers in Yukon, Canada. The Cryosphere, 9, 1183-1190. https://doi.org/10.5194/tc-9-1183-2015

Andersen, M. L., Stenseng, L., Skourup, H., Colgan, W., Khan, S. A., Kristensen, S. S., et al. (2015). Basin-scale partitioning of Greenland ice sheet mass balance components (2007-2011). Earth and Planetary Science Letters, 409, 89-95. https://doi.org/10.1016/j.epsl.2014.10.015

Andres, H. J., \& Peltier, W. R. (2013). Examining internal and external contributors to Greenland climate variability using CCSM3. Journal of Climate, 26, 9745-9773. https://doi.org/10.1175/JCLI-D-12-00845.1

Andrews, L. C., Catania, G. A., Hoffman, M. J., Gulley, J. D., Lüthi, M. P., Ryser, C., et al. (2014). Direct observations of evolving subglacial drainage beneath the Greenland Ice Sheet. Nature, 514, 80-83. https://doi.org/10.1038/nature13796

Bartholomew, I., Nienow, P., Mair, D., Hubbard, A., King, M. A., \& Sole, A. (2010). Seasonal evolution of subglacial drainage and acceleration in a Greenland outlet glacier. Nature Geoscience, 3, 408-411. https://doi.org/10.1038/NGEO863

Bevan, S. L., Luckman, A., Khan, S. A., \& Murray, T. (2015). Seasonal dynamic thinning at Helheim Glacier. Earth and Planetary Science Letters, 415, 47-53. https://doi.org/10.1016/j.epsl.2015.01.031

Bevan, S. L., Luckman, A. J., \& Murray, T. (2012). Glacier dynamics over the last quarter of a century at Helheim, Kangerdlugssuaq and 14 other major Greenland outlet glaciers. The Cryosphere, 6, 923-937. https://doi.org/10.5194/tc-6-923-2012

Brinkerhoff, D., \& O'Neel, S. (2017). Velocity variations at Columbia Glacier captured by particle filtering of oblique time-lapse images. CoRR. https://doi.org/abs/1711.05366

Cappelen, J. e. (2017). Weather Observations from Greenland 1958-2016-Observation data with description (DMI Report 17-08, Tech. rep.) Copenhagen: Danish Meteorological Institute.

Chu, W., Creyts, T. T., \& Bell, R. E. (2016). Rerouting of subglacial water flow between neighboring glaciers in West Greenland. Journal of Geophysical Research: Earth Surface, 121, 925-938. https://doi.org/10.1002/2015JF003705

Enderlin, E. M., Howat, I. M., Jeong, S., Noh, M., van Angelen, J. H., \& van den Broeke, M. R. (2014). An improved mass budget for the Greenland ice sheet. Geophysical Research Letters, 41, 866-872. https://doi.org/10.1002/2013GL059010

Hoffman, M. J., Andrews, L. C., Price, S. A., Catania, G. A., Neumann, T. A., Lüthi, M. P., et al. (2016). Greenland subglacial drainage evolution regulated by weakly connected regions of the bed. Nature Communications, 7(13903), 1-11. https://doi.org/10.1038/ncomms13903

Howat, I. M., Box, J. E., Ahn, Y., Herrington, A., \& McFadden, E. M. (2010). Seasonal variability in the dynamics of marine-terminating outlet glaciers in Greenland. Journal of Glaciology, 56(198), 601-613. https://doi.org/10.3189/002214310793146232

Howat, I. M., Joughin, I., Fahnestock, M., Smith, B. E., \& Scambos, T. A. (2008). Synchronous retreat and acceleration of southeast Greenland outlet glaciers 2000-06: Ice dynamics and coupling to climate. Journal of Glaciology, 54(187), 646-660. https://doi.org/10.3189/002214308786570908

Howat, I. M., Joughin, I., \& Scambos, T. A. (2007). Rapid changes in ice discharge from Greenland outlet glaciers. Science, 315, 1559-1561. https://doi.org/10.1126/science.1138478

Howat, I., Negrete, A., \& Smith, B. (2014). The Greenland Ice Mapping Project (GIMP) land classification and surface elevation data sets. The Cryosphere, 8, 1509-1518. https://doi.org/10.5194/tc-8-1509-2014

Howat, I., Negrete, A., \& Smith, B. (2015). MEaSURES Greenland Ice Mapping Project (GIMP) Digital Elevation Model, Version 1. Boulder, CO USA: NASA National Snow and Ice Data Center Distributed Active Archive Center. https://doi.org/10.5067/NV34YUIXLP9W

Joughin, I., Smith, B. E., \& Howat, I. (2018). Greenland Ice Mapping Project: Ice flow velocity variation at sub-monthly to decadal timescales. The Cryosphere, 12, 2211-2227. https://doi.org/10.5194/tc-12-2211-2018

Kamb, B., Engelhardt, H., Fahnestock, M. A., Humphrey, N., Meier, M., \& Stone, D. (1994). Mechanical and hydrologic basis for the rapid motion of a large tidewater glacier: 2. Interpretation. Journal of Geophysical Research, 99(B8), 15,231-15,244. https://doi.org/10.1029/94JB00467

Kehrl, L. M., Joughin, I., Shean, D. E., Floricioiu, D., \& Krieger, L. (2017). Seasonal and interannual variability in terminus position, glacier velocity, and surface elevation at Helheim and Kangerlussuaq Glaciers from 2008 to 2016. Journal of Geophysical Research: Earth Surface, 122, 1635-1652. https://doi.org/10.1002/2016JF004133

King, M. D., Howat, I. M., Jeong, S., Noh, M. J., Wouters, B., Noël, B., \& van de Broeke, M. R. (2018). Seasonal to decadal variability in ice discharge from the Greenland Ice Sheet. The Cryosphere, 12, 3813-3825. https://doi.org/10.5194/tc-12-3813-2018

Kjeldsen, K. K., Khan, S. A., Bjørk, A. A., Nielsen, K., \& Mouginot, J. (2017). Ice-dammed lake drainage in west Greenland: Drainage pattern and implications on ice flow and bedrock motion. Geophysical Research Letters, 44, 7320-7327. https://doi.org/10.1002/2017GL074081

Kusk, A., Merryman Boncori, J. P., \& Dall, J. (2018). An automated system for ice velocity measurement from SAR. In Proceedings of 12th European Conference on Synthetic Aperture Radar, Aachen, Germany, pp. 929-932

Lemos, A., Shepherd, A., McMillan, M., Hogg, A. E., Hatton, E., \& Joughin (2018). Ice velocity of Jakobshavn Isbræ, Petermann Glacier, Nioghalvfjerdsfjorden, and Zachariae Isstrøm, 2015-2017, from Sentinel-1 a/b SAR imagery. The Cryosphere, 12, $2087-2097$. https://doi.org/10.5194/tc-12-2087-2018

McNabb, R. W., Hock, R., \& Huss, M. (2015). Variations in Alaska tidewater glacier front ablation, 1985-2013. Journal of Geophysical Research: Earth Surface, 120, 120-136. https://doi.org/10.1002/2014JF003276

Meier, M., Lundstrom, S., Stone, D., Kamb, B., Engelhardt, H., Humphrey, N., et al. (1994). Mechanical and hydrologic basis for the rapid motion of a large tidewater glacier: 1. Observations. Journal of Geophysical Research, 99(B8), 15,219-15,229. https://doi.org/10.1029/94JB00237

Moon, T., \& Joughin, I. (2008). Changes in ice front position on Greenland's outlet glaciers from 1992 to 2007. Journal of Geophysical Research, 113, F02022. https://doi.org/10.1029/2007JF000927

Moon, T., Joughin, I., Smith, B., \& Howat, I. (2012). 21st-century evolution of Greenland outlet glacier velocities. Science, 336, 576-578. https://doi.org/10.1126/science.1219985

Moon, T., Joughin, I., Smith, B., van den Broeke, M. R., van de Berg, W. J., Noël, B., \& Usher, M. (2014). Distinct patterns of seasonal Greenland glacier velocity. Geophysical Research Letters, 41, 7209-7216. https://doi.org/10.1002/2014GL061836

Mouginot, J., Rignot, E., Scheuchl, B., Fenty, I., Khazendar, A., Morlighem, M., et al. (2015). Fast retreat of Zachariae Isstrøm, northeast Greenland. Science, 350(6266), 1357-1361. https://doi.org/10.1126/science.aac7111

Nagler, T., Rott, H., Hetzenecker, M., Wuite, J., \& Potin, P. (2015). The Sentinel-1 Mission: New opportunities for ice sheet observations. Remote Sensing, 7, 9371-9389. https://doi.org/10.3390/rs70709371

Potin, P., Rosich, B., Roeder, J., \& Bargellini, P. (2014). Sentinel-1 Mission operations concept. In 2014 IEEE Geoscience and Remote Sensing Symposium, pp. 1465-1468. https://doi.org/10.1109/IGARSS.2014.6946713

Quincey, D. J., Copland, L., Mayer, C., Bishop, M., Luckman, A., \& Belò, M. (2009). Ice velocity and climate variations for Baltoro Glacier, Pakistan. Journal of Glaciology, 55(194), 1061-1071. https://doi.org/10.3189/002214309790794913 
Rathmann, R. M., Hvidberg, C. S., Solgaard, A. M., Grinsted, A., Gudmundsson, G. H., Langen, P. L., et al. (2017). Highly temporally resolved response to seasonal surface melt of the Zachariae and $79^{\circ} \mathrm{N}$ outlet glaciers in northeast Greenland. Geophysical Research Letters, 44, 9805-9814. https://doi.org/10.1002/2017GL074368

Rignot, E., Braaten, D., Gogineni, S. P., Krabill, W. B., \& McConnell, J. R. (2004). Rapid ice discharge from southeast Greenland glaciers. Geophysical Research Letters, 31, L10401. https://doi.org/10.1029/2004GL019474

Schlegel, N. J., Larour, E., Seroussi, H., Morlighem, M., \& Box, J. E. (2014). Ice discharge uncertainties in Northeast Greenland from boundary conditions and climate forcing of an ice flow model. Journal of Geophysical Research: Earth Surface, 120, 29-54. https://doi.org/10.1002/2014JF003359

Stendel, M., Christensen, J. H., Adalgeirsdóttir, G., Kliem, N., \& Drews, M. (2007). Regional climate change for Greenland and surrounding seas-Danish Climate Centre Report 07-02 (Tech. rep.) Copenhagen: Danish Meteorological Institute.

Sugiyama, S., Skvarca, P., Naito, N., Enomoto, H., Tsutaki, S., Tone, K., et al. (2011). Ice speed of a calving glacier modulated by small fluctuations in basal water pressure. Nature Geoscience, 4(9), 597-600. https://doi.org/10.1038/ngeo1218

Sundal, A. V., Shepherd, A., Nienow, P., Hanna, E., Palmer, S., \& Huybrechts, P. (2011). Melt-induced speed-up of Greenland ice sheet offset by efficient subglacial drainage. Nature, 469, 521-524. https://doi.org/10.1038/nature09740

Torres, R., Snoeij, P., Geudtner, D., Bibby, D., Davidson, M., Attema, E., et al. (2012). GMES Sentinel-1 mission. Remote Sensing of Environment, 120(Supplement C), 9-24. https://doi.org/10.1016/j.rse.2011.05.028

Trusel, L. D., Frey, K. E., \& Das, S. B. (2012). Antarctic surface melting dynamics: Enhanced perspectives from radar scatterometer data. Journal of Geophysical Research, 117, F02023. https://doi.org/10.1029/2011JF002126

Van As, D., Fausto, R. S., \& Project Team PROMICE (2011). Programme for Monitoring of the Greenland Ice Sheet (PROMICE): First temperature and ablation records. Geological Survey of Denmark and Greenland Bulletin, 23, 73-76.

Veci, L. (2015). Sentinel-1 Toolbox. SAR Basics Tutorial: Array Systems Computing Inc. and European Space Agency.

Vieli, A., Jania, J., Blatter, H., \& Funk, M. (2004). Short-term velocity variations on Hansbreen, a tidewater glacier in Spitsbergen. Journal of Glaciology, 50(170), 389-398. https://doi.org/10.3189/172756504781829963

Vijay, S., \& Braun, M. (2017). Seasonal and interannual variability of Columbia Glacier, Alaska (2011-2016): Ice velocity, mass flux, surface elevation and front position. Remote Sensing, 9(635). https://doi.org/10.3390/rs9060635 